\title{
RESTRUKTURISASI PERBANKAN DAN DAMPAKNYA TERHADAP PEMULIHAN KEGIATAN EKONOMI DAN PENGENDALIAN MONETER
}

\author{
Halim Alamsyah*)
}

Krisis nilai tukar yang terjadi sejak pertengahan tahun 1997 telah mengakibatkan krisis perbankan yang parah di Indonesia. Kondisi ini mendorong dilakukannya restrukturisasi perbankan di Indonesiayang bertumpu kepadatiga strategi, yakni (a) bagaimana memulihkan kepercayaan terhadap perbankan nasional; (b) meningkatkan solvabilitas perbankan (penyelesaian masalah stock); dan (c) memberdayakan kembali operasional perbankan (penyelesaian masalah flow).

Evaluasi hingga awal tahun 1999 menunjukkan bahwa proses restrukturisasi perbankan tersebut relatif berjalan lamban. D ibandingkan dengan negara-negara A sia lainnya yang terkenakrisis perbankan dan dewasa ini sedang melakukan langkah restrukturisasi perbankan, proses restrukturisasi perbankan di Indonesia relatif tertinggal. H ingga dewasa ini proses restrukturisasi perbankan masih berada pada tahap penyelesaian masalah solvabil itas bank melalui program rekapital isasi. Biaya rekapital isasi jugadiperkirakan akan sangat besar, yakni mencapai sekitar Rp330 triliun atau 30\% dari PD B, yang sebagian besar akan dibiayai melalui penerbitan obligasi pemerintah. Kompleksnya permasal ahan yang dihadapi, tidak terdapatnya lembaga penanggung jawab pelaksanaan restrukturisasi perbankan yang mandiri, serta belum terdapatnya kesamaan visi secaranasional dalam penyelesaian masal ah solvabil itas perbankan nasional merupakan hambatan-hambatan utama yang berada dibaliktersen datnya program restrukturisasi perbankan di Indonesia.

Proses restrukturisasi perbankan yang relatiflamban tersebut menurut penulis akan membawa akibat tertundanya proses pemulihan kegiatan ekonomi Indonesia bila dibandingkan dengan negara-negaralain yang jugamengalami krisis ekonomi. Selain itu, program rekapitalisasi perbankan akan memberikan tekanan yang amat berat kepada posisi keuangan negara dalam jangkamenengah-panjang. Tanpaadanyalangkah-langkah penyesuaian di bidang fiskal serta penyempurnaan proses pengembalian dana rekapitalisasi yang transparen, cepat dan efisien maka pengendalian moneter akan menghadapi tantangan yang berat akibat membengkaknya defisit anggaran negaradi masa-masamendatang.

\footnotetext{
*) Halim Alamsyah : Deputi Kepala Urusan, Urusan Riset Ekonomi dan Kebijakan Moneter, BI, email : halamsyah @bi.go.id

Makalah ini merupakan penyempurnaan dari paper penulis sewaktu mengikuti SESPIBI Angkatan XXIII, AgustusNovember 1998. Penulis ingin mengucapkan terima kasih kepada Bp. Sukarwan MBM yang telah memberikan saran-saran berharga bagi penyempurnaan paper ini. Segala kekurangan dan kekeliruan tetap menjadi tanggung jawab penulis.
} 


\section{Pendahuluan}

$S$

ejak berlangsungnya krisis nilai tukar pada pertengahan tahun 1997 yang diikuti oleh krisis ekonomi terburuk dalam sejarah pembangunan ekonomi Indonesia, hingga awal tahun 1999 sistem perbankan semakin terpuruk parah. Posisi keuangan dan likuiditas perbankan nasional terus memburuk meskipun kecenderungan pelarian simpanan (deposit-runs) oleh masyarakat telah jauh berkurang bila dibandingkan dengan periode awal tahun 1998. Akibat besarnya mismatch yang dialami perbankan nasional, baik dari segi jangka waktu utang (maturity mismatch) dan mata uang (currrency mismatch), beban bunga dan utang luar negeri mendadak menggelembung ketika Rp menjadi sangat melemah. Selain itu, kredit bermasalah terus membengkak yang diperkirakan dapat mencapai lebih dari $70 \%$ total kredit perbankan akibat suku bunga yang naik tajam dan stagnasi kegiatan ekonomi. Dampak dari berbagai hal ini mengakibatkan kegiatan intermediasi perbankan praktis terhenti, permodalan bank menurun tajam, bahkan menjadi negatif sehingga secara teknis dunia perbankan Indonesia telah bangkrut.

Dengan situasi perbankan yang sakit parah tersebut, amat sulit di bayangkan bagaimana pemulihan kegiatan perekonomian nasional dapat terjadi. Oleh karena itu, dalam upaya melakukan stabilisasi dan mendorong pemulihan kegiatan perekonomian nasional, sejak pertengahan tahun 1998 Pemerintah mulai mengambil langkah-langkah konkrit menuju restrukturisasi perbankan nasional ${ }^{1}$. Pada tahap awal, langkah yang ditempuh dititikberatkan kepada upaya memulihkan kepercayaan kepada perbankan nasional. Selanjutnya, setelah upaya tersebut dapat meredam kepanikan dan kemungkinan timbulnya kerugian yang lebih besar lagi dalam sistem perbankan maka Pemerintah mulai menempuh langkah-langkah untuk menyehatkan posisi keuangan perbankan dan memperbaiki lingkungan operasional sistem perbankan. Patut dicatat bahwa berbagai langkah tersebut banyak yang berdimensi jangka menengah-panjang. Penilaian atas keberhasilan dari upaya-upaya tersebut dalam mengatasi dan mencegah berulangnya kembali krisis perbankan tentu saja tidak dapat dilakukan dengan mudah dan dalam waktu singkat.

Namun demikian, kata-kata bijak menyatakan bahwa pengalaman merupakan guru yang terbaik. A pa yang telah dilakukan oleh negara-negara lain yang pernah mengalami krisis perbankan tentu dapat menjadi pedoman atau bahan pembanding dalam melihat keberhasilan upaya melakukan restrukturisasi di bidang perbankan. Dalam kaitan ini pula pengalaman di berbagai negara seperti Cote d'Ivoire, Spanyol, Peru, dan Swedia menunjukkan bahwa program restrukturisasi perbankan merupakan bagian yang

1 Sebenarnya Pemerintah telah menyatakan akan melakukan restrukturisasi perbankan nasional sejak akhir tahun 1997. Namun, menurut penulis, pelaksanaannya belum dilakukan secara konsisten akibat berbagai faktor, antara lain, kesamaan visi dan sasaran restrukturisasi itu sendiri di tingkat pengambil keputusan. 
integral dari paket stabilisasi dan pemulihan kegiatan ekonomi ${ }^{2}$. Melalui pendekatan yang komprehensif, di negara-negara tersebut restrukturisasi perbankan telah memberikan dampak yang positif bagi upaya mendorong pertumbuhan ekonomi dan penurunan laju inflasi. Hal ini dapat terjadi karena pemulihan fungsi intermediasi perbankan secara efektif meningkatkan kembali mobilisasi dana, mereal okasi sumbersumber keuangan secara lebih efisien dan mendorong penurunan suku bunga. Dengan kondisi makroekonomi yang semakin terkendali, kepercayaan masyarakat dan investor secara berangsur-angsur pulih sehingga pada akhirnya memacu ekspansi permintaan dan penawaran aggregat.

Patut ditambahkan pula bahwa kesuksesan restrukturisasi perbankan itu sendiri juga tergantung kepada terciptanya situasi dan kondisi makroekonomi yang stabil dan keberhasilan langkah restrukturisasi di sektor riil $^{3}$. Pengalaman di negara-negara yang melakukan penyehatan perbankan dalam kondisi laju inflasi yang tinggi, misalnya, sering menghadapi gangguan terutama berupa proses disintermediasi di dalam sistem perbankan. Merosotnya kepercayaan kepada keamanan sistem perbankan mengakibatkan mobilisasi dana oleh perbankan dapat mengalami penurunan yang sangat tajam sehingga mengancam kehidupan bank yang pada dasarnya amat tergantung atas sumber dana dari masyarakat. Demikian pula bila kemacetan dan kerusakan yang dialami di sektor riil terus berlangsung, kinerja perbankan dalam mencapai keuntungan akan terganggu meskipun proses penyehatan bank telah dilakukan secara cermat.

Adanya saling keterkaitan ini menunjukkan bahwa rancang bangun dan strategi restrukturisasi perbankan tidaklah cukup bila hanya memperhitungkan aspek mikro penyehatan bank saja. Pengalaman di berbagai negara menunjukkan bahwa kesuksesan restrukturisasi perbankan akan tergantung pula kepada konsistensinya dengan upaya menjaga kestabilan moneter. Konsistensi ini akan semakin diperlukan bila strategi restrukturisasi perbankan akan melibatkan dana/ subsidi pemerintah ataupun bank sentral dalam jumlah yang terkadang sangat besar. Walaupun dari sudut mikro penyediaan dana ini berdampak positif kepada penyelesaian masalah perbankan, secara makroekonomi hal tersebut kemungkinan akan dapat menimbulkan konflik dengan upaya menjaga kestabilan moneter dan disiplin anggaran. Oleh karena itu, trade-off yang muncul merupakan suatu hal yang perlu dicermati agar restrukturisasi perbankan dapat berjalan dengan baik sementara kestabilan makroekonomi dan pemulihan perekonomian dapat dicapai.

Dengan latar belakang permasalahan di atas, makalah ini mencoba menganalisis strategi restrukturisasi perbankan di Indonesia dan dampaknya kepada pengendalian

2 Lihat W.E. Alexander et.al, Systemic Bank Restructuring and Macroeconomic Policy, 1997, hal.117

3 Lihat Andrew Sheng, Bank Restructuring: Techniques and Experience, Washington D.C.,1992. 
moneter dan keuangan negara serta upaya pemulihan kegiatan ekonomi. Sebagai studi komparatif, pada Bab 2 akan diuraikan pengalaman restrukturisasi perbankan di berbagai negara. Fokus penguraian ditujukan untuk menggambarkan praktik-praktik terbaik (best practices) secara internasional dalam restrukturisasi perbankan. Selanjutnya Bab 3 akan menguraikan secara ringkas strategi restrukturisasi perbankan di Indonesia. Bahasan akan mencakup ulasan tentang langkah-langkah kebijakan yang telah maupun yang akan ditempuh. Dalam Bab 4 akan diuraikan analisis dampak makroekonomi dari restrukturisasi perbankan Indonesia dengan menitikberatkan kepada dampak dari penyehatan bank kepada kemantapan moneter dan fiskal. Selanjutnya, Bab 5 menyajikan kesimpulan dan pilihan kebijakan yang dapat ditempuh serta pelajaran yang dapat ditarik dari pengalaman menghadapi krisis sebagai penutup makalah ini.

\section{Restrukturisasi Perbankan: Pengalaman di Berbagai N egara}

Dalam sejarah keuangan modern, krisis perbankan telah terjadi silih berganti di berbagai kawasan dan negara di dunia. Menurut studi IMF (1997) dalam kurun waktu lima belas tahun terakhir terdapat sekitar 30 negara yang telah melakukan program restrukturisasi perbankan secara sistemik ${ }^{4}$ sebagai respons terhadap krisis yang terjadi. Suatu hal yang menarik adalah bahwa studi tersebut menyimpulkan bahwa tidak ada suatu strategi yang unik dan dapat diberlakukan secara umum bagi penyelesaian semua kasus krisis perbankan mengingat kompleksnya permasalahan yang dihadapi ${ }^{5}$. Meskipun demikian, studi tersebut menemukan adanya sejumlah kecenderungan umum yang cukup "robust" dalam berbagai program restrukturisasi perbankan yang dinilai sukses di banyak negara rujukan ${ }^{6}$. Penemuan tersebut menjadi motivasi pembahasan dalam dalam Bab ini dengan mencoba mengidentifikasi secara ringkas beberapa "best practices" dari suatu program restrukturisasi perbankan yang berhasil.

\subsection{R estrukturisasi perbankan sebagai bagian integral dari paket stabilisasi dan pemulihan ekonomi}

Di banyak negara yang dinilai berhasil dalam melaksanakan restrukturisasi perbankan yang sistemik menempatkan program tersebut dalam suatu paket stabilisasi dan pemulihan ekonomi. Motivasi yang melandasi strategi tersebut pada dasarnya

4 Program restrukturisasi perbankan bersifat sistemik bila cakupannya komprehensif dan menyangkut sebagian besar sistem perbankan guna memperbaiki kinerja perbankan sebagai lembaga intermediasi secara berkesinambungan.

5 Lihat V. Sundararajan dan T. Balino, Banking Crises: Cases and Causes, IMF, 1991

6 Dimaksudkan sebagai negara-negara yang dianggap berhasil mengembalikan kesehatan sistem perbankan mereka melalui program restrukturisasi perbankan dengan relatif cepat dan biaya yang minimal. Menurut studi IMF (1997) negara-negara yang dianggap sangat berhasil (substantial progress countries) antara lain adalah Swedia, Cote d'Ivoire, Spanyol. 
didorong oleh kenyataan bahwa proses penyehatan perbankan secara mikro memiliki pula dampak makroekonomi yang penting untuk dikendalikan.

Dampak makroekonomi dari restrukturisasi perbankan secara ringkas dapat dilihat dari sudut fiskal, moneter, dan permintaan atau penawaran aggregat. Dari aspek fiskal, intervensi pemerintah dan bank sentral dalam proses restrukturisasi perbankan seringkali membawa beban fiskal ataupun quasifiskal yang berat. Tidak jarang hal ini mengakibatkan defisit fiskal dan peningkatan utang pemerintah yang amat besar sehingga mengganggu kestabilan makroekonomi. Dari aspek moneter, upaya melindungi sistem pembayaran nasional dari kelumpuhan akibat pelarian-simpanan yang sistemik seringkali pula memerlukan tindakan darurat berupa pemberian likuiditas dari bank sentral sebagai lender of the last resort. Namun, hal ini akan mengakibatkan ekspansi uang beredar yang seringkali sangat besar dan mungkin akan bertentangan dengan tujuan meredam tekanantekanan terhadap inflasi dan nilai tukar yang biasanya muncul dalam situasi krisis keuangan yang sistemik. Proses restrukturisasi perbankan juga akan dapat mempengaruhi ketersediaan dan proses alokasi kredit sehingga respons dari kegiatan produksi dan investasi akan tergantung kepada seberapa cepat restrukturisasi perbankan dilakukan. Selain itu, alokasi "loss" (allocation of loss) dalam proses restrukturisasi perbankan akan mempengaruhi

\author{
Box 1. Instrumen Restrukturisasi Perbankan \\ Efektif dari segi biaya (cost effective) \\ Sederhana pelaksanaannya \\ Dapat mengalokasi loss secara adil \\ Beban minimum bagi APBN \\ Mendorong internal governance \\ Konsisten dengan kebijakan makro \\ Sumber: WE Alexander et.al (1997)
}

Komprehensif. Cakupan restrukturisasi perbankan tidak hanya menyangkut penyelesaian masalah stock dan flow dari bank yang lemah dan insolvent saja, tetapi juga mengkoreksi kelemahan di bidang akunting, legal dan aturan prudential, supervisi dan compliance.

Prompt action. Di negara-negara rujukan umumnya tindakan diambil dalam periode satu tahun setelah permasalahan diketahui.

- Exit policy yang tegas. Pembekuan/penutupan bank merupakan bagian integral dari best practice apabila kondisi krisis telah dapat dikendalikan. Pengalaman di Chile dan Amerika Serikat menunjukkan tidak ada too big to fail .

Badan pengendalilead agency yang efektif akan mempermudah pelaksanaan restrukturisasi perbankan. Swedia membentuk badan pengendali baru. Di Amerika Serikat dan Spanyol, badan penjamin simpanan mereka yang mengambil pimpinan. Bank sentral sering merangkap sebagai badan pengendali, namun sering terjadi bank sentral terpaksa ikut membiayai program restrukturisasi sehingga menimbulkan konflik dengan tugasnya sebagai otoritas moneter. Sementara koordinasi antara pemerintah, bank sentral, dan badan supervisi perbankan sangat penting, badan pengendali harus memiliki independensi yang cukup dan mendapatkan dukungan dari otoritas tertinggi di suatu negara.

Sumber: W.E. Alexander et.al (1997)
Box 2. Strategi Restrukturisasi Perbankan 
kekayaan dari para pemilik bank, kreditur bank, dan deposan, sehingga memiliki dimensi sosial dan politik yang cukup sensitif bila tidak ditangani secara baik.

Dengan menyadari terdapatnya berbagai aspek makro di atas, restrukturisasi perbankan di banyak negara rujukan umumnya dirancang dalam suatu program yang bersifat komprehensif, mencakup baik upaya penyehatan individual bank dan sistem perbankan maupun pertimbangan dampaknya bagi pemulihan kondisi makroekonomi. Konflik dalam mencapai sasaran mikro dan makro seperti diuraikan di atas seringkali tidak terhindarkan. Namun, pengalaman di negara-negara rujukan menunjukkan bahwa konflik akan dapat dikendalikan apabila pilihan instrumen yang digunakan dapat meminimalkan moral hazard, menggunakan biaya yang minimum, serta menciptakan sistem insentif yang sehat bagi pemilik dan pengelola bank untuk senantiasa memelihara kesehatan bank secara berkesinambungan (Lihat Box 1).

Patut dikemukakan bahwa keputusan untuk melakukan restrukturisasi perbankan yang komprehensif di negara-negara rujukan tersebut mencerminkan kemampuan mereka mengenali luas dan dalamnya permasalahan (proper diagnosis) serta adanya visi yang jelas mengenai arah penyelesaian krisis perbankan yang dihadapi ${ }^{7}$. Hal-hal ini memungkinkan langkah-langkah korektif yang diambil dapat ditempuh dengan cepat (prompt action) sehingga ikut mengurangi terjadinya kerugian yang lebih besar seandainya proses restrukturisasi ditunda-tunda.

\subsection{Strategi restrukturisasi perbankan}

Program restrukturisasi perbankan yang komprehensif memiliki sasaran untuk menyehatkan posisi keuangan dan operasional bank secara individu, mengatasi kelemahan dan kekurangan yang terdapat di dalam lingkungan operasi dan konfigurasi sistem perbankan, serta memulihkan kepercayaan masyarakat. M eskipun tidak ada suatu resep yang dapat berlaku secara umum, pengalaman di negara-negara rujukan menunjukkan bahwa selain komprehensif, suatu strategi restrukturisasi perbankan yang berhasil memiliki ciri-ciri dapat dilaksanakan dengan cepat (prompt action), menerapkan exit policy yang tegas, serta memiliki suatu badan pengendali (lead agency) yang berwenang penuh melaksanakan restrukturisasi perbankan (Lihat Box 2).

Secara teknis, inti dari setiap strategi restrukturisasi perbankan menyangkut upaya mempercepat penyelesaian masalah solvabilitas (masalah stock) dan pemulihan

7 Dari sudut manajemen krisis, kemampuan yang tinggi dalam melakukan pemetaan permasalahan yang dihadapi serta kemudian diikuti oleh analisis masalah dan pengambilan keputusan secara cepat dan tepat merupakan ciri dari suatu manajemen krisis yang efektif. Lihat Anugerah Pekerti Ph.D, "Manajemen Krisis", Presentasi dalam SESPIBI XXIII, Jakarta, Oktober 1998 
profitabilitas (masalah flow) perbankan. Penyelesaian masalah stock berkaitan dengan neraca suatu bank, yakni di sisi aktiva akan terkait terutama dengan penyelesaian kredit bermasalah sedangkan di sisi pasiva akan lebih berkaitan dengan upaya rekapitalisasi bank. Instrumen yang banyak digunakan dalam penyelesaian masalah stock ini dapat dilihat pada lampiran 1 .

Namun, penyelesaian masal ah solvabilitas saja tidaklah cukup untuk menyehatkan sistem perbankan secara berkesinambungan. Upaya pemulihan profitabilitas dan pencegahan munculnya kembali kerugian harus pula dilakukan segera setelah masalah stock dapat diselesaikan atau paling tidak setelah program yang jelas telah dimiliki. Hal ini terutama berkaitan dengan penyempurnaan sistem akunting, kerangka hukum dan ketentuan prudensial yang melandasi operasi bank, struktur kelembagaan serta penyempurnaan supervisi perbankan. Patut dikemukakan, survei yang dilakukan IMF (1997), menemukan banyak negara yang berhasil dalam menyelesaikan masalah stock, tetapi hanya sebagian saja yang berhasil memecahkan masalah flow. Fakta ini menunjukkan bahwa strategi restrukturisasi perbankan yang baik harus mencakup penyehatan individual bank dan sistemnya, serta lingkungan eksternal yang kondusif bagi kesehatan operasionalnya.

Secara garis besar strategi restrukturisasi perbankan yang ditempuh di banyak negara dapat dilihat dari tiga aspek, yakni:

a. Bagaimana menstabilkan sistem keuangan/perbankan secepat mungkin. Strategi yang diterapkan disini bertujuan untuk meredam krisis, memulihkan kepercayaan deposan, dan melindungi sistem pembayaran nasional secepat mungkin. Namun, dalam situasi situasi krisis yang sistemik dengan pelarian simpanan yang sangat besar maka strategi kebijakan dan instrumen yang tersedia menjadi amat terbatas. Oleh karena itu, di banyak negara penyediaan likuiditas oleh bank sentral sebagai lender of the last resort, dan likuiditas darurat lainnya seperti kemudahan overdraft bagi bank-bank sering dilakukan bila fasilitas likuiditas yang normal tidak mencukupi. Di beberapa negara seperti Swedia, Turki, Finlandia, Thailand, dan Korea penerapan skim jaminan yang menyeluruh (blanket guarantee sheme) baik kepada deposan maupun kreditur menjadi bagian yang cukup berhasil dalam menstabilkan sistem keuangan secara menyeluruh ${ }^{8}$. $\mathrm{N}$ amun, keberhasilan dari strategi ini akan sangat tergantung kepada kemampuan untuk meminimalkan moral hazard baik melalui

8 Blanket guarantee scheme di Swedia hampir mirip dengan program serupa di Indonesia karena menjamin juga transaksi adminsitratif perbankan. Hanya dalam pelaksanaannya, pembayaran atas transaksi administratif tersebut ternyata tidak/belum sampai terjadi. 
penalti suku bungayang tinggi ataupun bentuk penalti nonmoneter seperti penggantian manajemen, penguasaan aset/ kepemilikan bank, dan sebagainya.

b. Bagaimana menyelesaikan masalah solvabilitas (stock) bank. Setelah krisis dapat dikendalikan maka restrukturisasi perbankan diarahkan untuk memulihkan kesehatan posisi keuangan perbankan melalui restrukturisasi keuangan (financial restructuring), baik di sisi aktiva maupun sisi pasiva. Instrumen yang digunakan di banyak negara sangat bervariasi tergantung kepada sumber dan intensitas permasalahan yang dihadapi (lihat Lampiran 1). Masalah yang akan dihadapi adalah bagaimana dampak dari instrumen yang digunakan kepadakondisi moneter dan fiskal, distribusi kerugian yang dibebankan kepada pemerintah, pemilik bank, kreditur, dan deposan, serta efektivitas pengembalian kredit bermasalah (loan recovery). Hal-hal ini akan kritikal bagi pengendalian moneter yang independen dan pengurangan moral hazard.

c. Bagaimana mendorong perbankan kembali beroperasi secara sehat. Seperti disinggung sebelumnya, penyehatan posisi keuangan bank tidak akan lengkap bila tidak diikuti oleh perbaikan lingkungan eksternal tempat beroperasinya perbankan (restrukturisasi operasional). Oleh karena itu, strategi restrukturisasi perbankan dalam tahap restrukturisasi operasional diarahkan untuk menjawab kelemahan-kelemahan yang ada dal am sistem akunting, konfigurasi sektor perbankan dan kerangka hukum yang akan mempengaruhi gerak operasional perbankan di masa depan. Dalam praktiknya, langkah-langkah yang diambil di banyak negara berkaitan dengan upaya menciptakan sistem perbankan yang dapat mendorong disiplin pasar (market discipline) melalui kompetisi dan exit-policy yang tegas. Dilihat dari sisi otoritas perbankan maka ini berarti akan menyangkut pula penyempurnaan aspek kerangka hukum dan supervisi perbankan.

\subsection{A spek hukum dan politik dari restrukturisasi perbankan}

Pengalaman di berbagai negara menunjukkan bahwa restrukturisasi perbankan secara sistemik merupakan suatu proses yang panjang (multi-tahun) dan penyelesaiannya sering bersinggungan dengan dimensi sosial dan politik. Hal ini dapat dimengerti mengingat krisis perbankan yang sistemik memberikan dampak negatif yang amat luas di dalam suatu perekonomian. Munculnya resistensi terhadap perubahan drastis yang diperlukan dalam mengatasi krisis perbankan mengakibatkan banyaknya benturan kepentingan, baik di tingkat pemerintahan, dunia usaha, maupun masyarakat luas. Dalam banyak kasus, penyelesaian konflik yang kurang efektif akibat ketiadaan konsensus nasional dan dukungan politik serta landasan hukum yang tegas menjadikan proses restrukturisasi perbankan tertunda-tunda. A pabila ini terjadi maka program restrukturisasi 
perbankan akan berjalan sangat lambat dan pada akhirnya memerlukan langkah korektif yang lebih drastis dan biaya fiskal yang amat besar ${ }^{9}$.

Pengalaman di Swedia merupakan contoh suatu proses restrukturisasi perbankan yang berhasil karena dapat dijalankan dengan cepat dan biaya yang relatif kecil berkat adanya dukungan yang kuat dari sisi politik dan hukum. Dalam kasus lain, penyelesaian krisis perbankan sering tertunda-tunda karena tidak adanya visi yang sama dan badan pengendali restrukturisasi perbankan yang kuat dan independen. Berdasarkan pengamatan ini, Andrew Sheng (1992) menyimpulkan bahwa keberhasilan restrukturisasi perbankan memerlukan kondisi-kondisi umum ${ }^{10}$ :

a. Terciptanya kondisi makroekonomi yang stabil dan sektor riil yang kompetitif

b. Kemauan politik yang kuat untuk melakukan restrukturisasi

c. Perangkat institusi dan instrumen restrukturisasi perbankan yang efektif

d. Ketentuan hukum (legal framew ork) yang mampu menciptakan disiplin keuangan

Keempat aspek di atas menunjukkan bahwa kelancaran dan keberhasilan program restrukturisasi perbankan akan menyangkut konsistensi program tersebut dengan aspek makro, mikro, kelembagaan dan aturan hukum yang melandasi bekerjanya sistem perbankan. Dua di antaranya terkait dengan pentingnya peranan dukungan politik dan hukum dalam keseluruhan proses restrukturisasi perbankan.

\section{Strategi Restrukturisasi Perbankan di Indonesia}

Secara umum, arsitektur strategi restrukturisasi perbankan di Indonesia memiliki kesamaan dengan yang ditempuh di berbagai negara lainnya ${ }^{11}$. Bila diukur dengan pendekatan yang disarankan oleh Gilian Garcia12 maka tingkat kemajuan restrukturisasi perbankan di Indonesia dalam penyelesaian krisis berada dalam tahap pemulihan kepercayaan kepada sistem perbankan dan persiapan menuju tahap penyelesaian restrukturisasi keuangan perbankan secara sistemik. Sementara itu, tahap penyelesaian restrukturisasi operasional yang lebih menekankan perbaikan lingkungan eksternal tempat beroperasinya perbankan masih berada dalam tahap awal .

9 Kasus di Chile menjadi contoh suatu program restrukturisasi perbankan yang berjalan amat lambat, dimulai dari awal tahun 1980an dan hingga dewasa ini bahkan belum sepenuhnya selesai. Biaya restrukturisasi perbankan diperkirakan telah mencapai sekitar 33\% dari PDB

10 Disarikan dari Andrew Sheng (1992), halaman 30

$11 \mathrm{Hal}$ ini terutama karena pengaruh IMF yang banyak terlibat dalam restrukturisasi perbankan di berbagai negara.

12 Lihat tulisan Gilian Garcia, A Framework for Analysis and Assessment, di dalam buku W.E. Alexander et.al, Systemic Bank Restructuring and Macroeconomic Policy, IMF, 1997, halaman 42-74. 
Secara garis besar, restrukturisasi perbankan di Indonesia dapat dipisahkan menjadi tiga strategi utama, yakni:13

\subsection{Strategi pemulihan kepercayaan kepada perbankan}

Ketika krisis perbankan nasional semakin mendalam menjelang akhir tahun 1997 akibat menghebatnya tekanan pelarian simpanan, pilihan kebijakan yang dapat ditempuh dan waktu yang tersedia pada dasarnya menjadi amat terbatas. Di sisi lain, risiko yang dihadapi amat besar apabila proses intermediasi perbankan terhenti karena akan mengakibatkan macetnya sistem pembayaran nasional dan kelumpuhan kegiatan perekonomian secara menyeluruh. Oleh karena itu, strategi yang ditempuh dalam situasi darurat ini pada awalnya adalah dengan mencoba menanamkan kepercayaan kepada masyarakat bahwa pemerintah dan bank sentral akan bertindak sebagai pelindung simpanan masyarakat (deposits protector). Namun, komitmen yang ingin ditanamkan pemerintah/ bank sentral ternyata tidak segera memperoleh kepercayaan sehingga pelarian dana bank terus berlanjut. Hal ini memaksa Bank Indonesia menyediakan bantuan likuiditas ${ }^{14}$ (BLBI) dalam fungsinya sebagai lender of thelast resort dan kemudian diperkuat lagi oleh dukungan skim penjaminan menyeluruh (blanket guarantee scheme) dari Pemerintah. Strategi ini kemudian dapat meredam kepanikan yang terjadi secara berangsur-angsur walau selama beberapa bulan pertama ternyata tidak berhasil.

Pada awal krisis, penyediaan likuiditas kepada perbankan secara normal diberikan dalam bentuk fasilitas diskonto, pinjaman subordinasi, dan kredit likuiditas darurat. Dalam perkembangannya, fasilitas-fasilitas ini sebagian sudah dihentikan pada saat Ionjakan permintaan dana dari bank meningkat pesat akibat sangat besarnya pelarian simpanan. Bank Indonesia kemudian memperkenankan bank-bank melakukan overdraft pada rekening giro mereka di Bank Indonesia ${ }^{15}$. Namun, dengan terus berlanjutnya krisis kepercayaan kepada perbankan, Pemerintah pada bulan Januari 1998 mengumumkan berlakunya blanket guarantee scheme yang menjamin pembayaran kepada deposan dan kreditur dalam dan luar negeri, serta beberapa jenis transaksi administratif (off balance sheet).

Skim penjaminan ini yang semula diharapkan dapat meredam pelarian simpanan, ternyata mempunyai implikasi sebaliknya. Bank yang semula menahan nasabah untuk

13 Restrukturisasi perbankan menurut penulis mencakup pula strategi yang ditempuh sewaktu krisis perbankan mulai terjadi (tindakan darurat). Walaupun pilihan kebijakan relatif terbatas dalam situasi krisis, restrukturisasi perbankan yang baik mengharuskan adanya konsistensi tindakan darurat dengan visi dan arah penyelesaian yang lebih struktural. Lihat pula V. Sundararajan dan T. Balino (1991) tentang tiga aspek penyelesaian krisis perbankan, halaman 35.

14 Istilah bantuan likuiditas sebenarnya tidak tepat karena fasilitas tersebut mengandung penalti suku bunga yang sangat tinggi di atas bunga pasar, dengan jaminan (collateralized), dan harus dikembalikan kembali oleh bank.

15 Berdasarkan keputusan rapat Direksi Bank Indonesia bulan Agustus 1997. 
tidak ikut menarik simpanan, justru ikut mempermudah prosesnya setelah skim penjaminan diadakan. Akibatnya, penyediaan dana oleh Bank Indonesia yang hampir seluruhnya berasal dari overdraft dan istilahnya kemudian dipopulerkan sebagai BLBI menjadi biaya yang sangat besar atas beban fiskal dan perekonomian (berupa inflasi dan tingginya suku bunga), selain muncul masalah moral hazard yang serius dalam pelaksanaannya. Hal yang terakhir ini antara lain juga karena terlambatnya pengenaan penalti suku bungayang tinggi terhadap overdraft ${ }^{16}$ serta belum jelasnya visi dan strategi penyelesaian restrukturisasi perbankan pada awal-awal masa krisis yang mengakibatkan terus meningkatnya overdraft bank-bank yang sebenarnya telah insolvent.

\subsection{Strategi penyelesaian masalah solvabilitas bank}

Krisisyang berkepanjangan pada akhirnya mengakibatkan hampir seluruh perbankan nasional mengalami masalah kekurangan permodalan yang sangat parah. Menghadapi perkembangan ini, strategi yang ditempuh untuk menangani bank bermasalah, khususnya yang mempunyai kewaji ban kepada Pemerintah/ Bank Indonesia dalam bentuk BLBI, pada awalnya adalah dengan membentuk Badan Penyehatan Perbankan Nasional (BPPN) dan melakukan rekapitalisasi, sementara atas kredit dan debitur bermasalah ditangani melal ui pembentukan Asset Management Unit (AMU). Namun, patut dicatat sejak tanggal 19 Juni 1998, fungsi pengawasan bank-bank di bawah BPPN (dan program penjaminan) telah dikembalikan ke Bank Indonesia sehingga peran BPPN hanya kepada penyehatan bank, termasuk pengelolaan $\mathrm{AMU}$.

Pembentukan BPPN sebagai "rumah sakit" bank-bank bermasalah tampaknya didasarkan kepada pemikiran perlunyasuatu badan pengendali (lead agency) yang independen dalam melakukan tugas penyehatan bank sekaligus bertindak sebagai pengendali kebocoran (bl eeding) dari BLBI guna mengurangi moral hazard dari bank penerima BLBI. Oleh karenaitu, BPPN dalam tindakannya telah melakukan pengam-bilalihan (Bank Take Over atau BTO) atau pembekuan operasi bank (Bank Beku Operasi atau BBO) atas bank yang dianggap memenuhi kriteriauntuk dilakukan $\mathrm{BTO}$ dan $\mathrm{BBO}^{17}$.

Langkah selanjutnya adalah melakukan rekapitalisasi atas bank-bank yang dinilai memiliki prospek untuk disehatkan kembali. Sebagai langkah awal, keseluruhan perbankan di Indonesia dewasa ini telah diidentifikasi dan dikelompokkan dalam tiga kategori: yang

16 Pengenaan penalti berupa suku bunga yang jauh di atas suku bunga pasar baru dilakukan sekitar 2 bulan setelah BLBI menjadi tidak terkendali melalui Surat Keputusan Direksi Bank Indonesia Maret 1998.

17 Kriteria suatu bank masuk dalam pengawasan BPPN adalah CAR bank $<$ atau $=5 \%$ dan total BLBI $>200 \%$ modal bank. Kriteria untuk BTO adalah BLBI > 500\% modal bank dan total BLBI > Rp2 triliun, sedangkan untuk BBO jumlah BLBI $>$ atau $=75 \%$ dari total aktiva bank dan tidak memiliki prospek. Hingga dewasa ini tercatat 55 bank menjadi "pasien" BPPN, terdiri dari $10 \mathrm{BTO}, 11 \mathrm{BBO}$, dan sisanya non BTO/BBO. 
sehat (A), yang masih dapat disehatkan (B), dan yang akan diambil tindakan khusus (C) ${ }^{18}$. Bagi bank kategori B dan $C$ akan diminta menambah modal sehingga mencapai CAR minimal 4\%. Menyadari bahwa pemi lik bank atau investor tidak mampu menyediakan dana untuk penambahan modal tersebut, tampaknyatidak dapat dihindari lagi keikutsertaan pemerintah dalam penambahan modal bank. Oleh karena itu, penyertaan modal pemerintah akan dilakukan melalui instrumen konversi BLBI dan penerbitan obligasi pemerintah. Berdasarkan informasi sementara, untuk membiayai program rekapitalisasi tersebut Pemerintah membutuhkan dana sedikitnya Rp330 triliun. Dari jumlah tersebut, sejumlah Rp290triliun merupakan penyertaan modal Pemerintah sedangkan sisanya akan digunakan untuk memperlancar penyelesaian bank-bank BBO dan biaya untuk pemindahan dan pengel olaan aset bermasalah bank-bank keAMU. Pendanaan tersebut akan bersumber dari penerbitan obligasi pemerintah yang berjangka waktu 5 tahun dengan rincian sebagai berikut.

a. Penerbitan obligasi dengan kupon inflation-indexed plus 3\% sejumlah Rp150triliun untuk membiayai konversi BLBI menjadi penyertaan modal Pemerintah. Obligasi ini akan menggantikan tagihan Bank Indonesia dari perbankan menjadi tagihan kepada Pemerintah.

b. Penerbitan obligasi dengan kupon mengikuti suku bunga SBI sejumlah Rp160triliun.

c. Penerbitan obligasi dengan kupon suku bunga tetap (sekitar 15\%) sejumlah Rp20triliun.

Penyertaan modal pemerintah dilakukan setelah pemilik atau investor bank yang dinilai layak (kategori B) melunasi BLBI dan menurunkan pelanggaran BMPK satu bulan sejak rencana usaha (business plan) bank tersebut disetujui oleh Bank Indonesia. Selanjutnya, pemilik atau investor diminta menambah modal dan untuk setiap Rp1,- tambahan modal, pemerintah akan memasukkan modal maksimal Rp4,- atau maksimum 80\% dari total kebutuhan tambahan modal. ${ }^{19}$ Sementara itu, penyelesaian kredityang telah tergolong macet wajib dihapusbukukan dan diserahkan kepada AMU-BPPN dengan nilai buku nihil.

Evaluasi sementara atas program restrukturisasi keuangan perbankan nasional menurut hemat penulis menunjukkan proses yang relatif belum berjalan lancar. Padatahap awal pelaksanaan program restrukturisasi perbankan telah terjadi penundaan dan perubahan modalitas penyelesaian bank-bank bermasalah, terutama dalam bentuk pengembalian fungsi pengawasan BPPN kepadaBank Indonesia. A khir-akhir ini kontroversi atas keterlibatan dana pemerintah dalam kebijakan rekapitalisasi terutama oleh pihak Dewan Perwakilan Rakyat mulai terdengar yang dikhawatirkan akan menjadi hambatan yang

18 Kelompok A adalah bank dengan CAR lebih dari 4\%, kelompok B adalah CAR antara $4 \%$ s.d. $-25 \%$, dan kelompok $\mathrm{C}$ adalah CAR dibawah $-25 \%$.

19 Penjelasan Gubernur Bank Indonesia dalam press release tanggal 21 September 1998. 
signifikan dalam proses restrukturisasi perbankan. Hal-hal ini mengakibatkan proses restrukturisasi perbankan di Indonesia relatif tertinggal dibandingkan dengan negara-negara tetangga yang juga melakukan langkah yang sama. Tampaknya tanpa kesamaan visi dalam penyelesaian krisis perbankan secara nasional, koordinasi yang lemah akibat tidak terdapatnya suatu badan pengendali yang efektif dan independen ${ }^{20}$, serta dukungan politis dan hukum yang kurang memadai akan mengakibatkan proses restrukturisasi perbankan di Indonesia berjalan lambat.

\subsection{Strategi pemberdayaan perbankan}

Secara umum, strategi pemberdayaan perbankan yang pada dasarnya berupaya mendorong internal governance bank yang sehat dan penciptaan lingkungan eksternal yang kondusif belum tergambarkan dengan jelas. Hingga dewasa ini, langkah-langkah yang telah ditempuh dititikberatkan kepada upaya mendorong penciptaan disiplin pasar dan peningkatan kompetisi antara melalui penyempurnaan peraturan perundang-undangan yang terkait dengan aspek pengurangan cakupan rahasia bank, penghapusan batasan kepemilikan oleh asing, dan perlakuan yang sama atas bank asing / campuran ${ }^{21}$. Dari aspek supervisi, strategi yang ditempuh adalah memperkuat wewenang Bank Indonesia sebagai otoritas perbankan dengan mengalihkan wewenang perizinan bank dari Departemen Keuangan keBank Indonesia. Selain itu, dilakukan pula penyempurnaan ketentuan kehatihatian yang terkait dengan perluasan kualitas aktiva produktif dan penyisi han penghapusan aktiva produktif sesuai dengan standar perbankan internasional. Namun, strategi yang menyangkutstruktur kelembagaan masih belum jelas meskipun perencanaan untuk memiliki sejumlah bank yang sehat, besar, dan profesional (core bank strategy) sedang dikaji kemungkinan penerapannya di Indonesia ${ }^{22}$.

Sementara itu, strategi yang ditempuh dalam menghadapi lingkungan eksternal yang tidak kondusif bagi operasi perbankan akibat tingginya suku bunga adalah dengan mengikutsertakan bank-bank dalam program pengembangan usaha kecil dengan suku bunga rendah dan subsidi dana sepenuhnya dari Bank Indonesia. M eskipun demikian, keberhasilan dari upaya ini masih belum dapat dipastikan, di samping karena peranannya dalam keseluruhan aset perbankan yang relatif kecil.

Secara keseluruhan, strategi pemberdayaan perbankan tampaknya memerlukan pengembangan arah dan pola yang lebih jelas. Penyempurnaan beberapa ketentuan

20 Pada tanggal 21 Agustus 1998 telah dibentuk"Financial Sector Action Committee", dengan anggotanya Menko EKUIN, Menperindag, dan Ketua Bappenas guna meningkatkan koordinasi dengan departemen terkait dalam rangka restrukturisasi perbankan. Seberapa efektif forum koordinasi ini masih harus dilihat hasil kerjanya.

21 Amandemen Undang-Undang No.7/1992 tentang Perbankan.

22 Lihat Maulana Ibrahim, "Strategi Restrukturisasi Perbankan" presentasi pada SESPIBI XXIII, Oktober 1998. 
prudential dan kerangka hukum dan supervisi guna mendorong internal governance yang sehat memang telah dilakukan. Namun, masalah yang juga strategis terutama yang menyangkut mengenai konfigurasi industri perbankan masa depan serta penciptaan lingkungan eksternal yang lebih kondusif bagi beroperasinya bank secara sehat tampaknya masih dalam tahap awal. Dalam kasus Indonesia, masalah lingkungan eksternal justru semakin pelik dengan relatif masih tingginya suku bunga akibat pengetatan moneter yang mengakibatkan perbankan mengalami "negative-spread" dan semakin tidak berdaya. Oleh karena itu, tanpa diikuti oleh strategi restrukturisasi operasional bank yang direncanakan secara matang dikhawatirkan perbankan nasional akan mengalami permasalahan kembali di kemudian hari, seperti yang banyak terjadi di negara-negara lain yang melupakan aspek ini.

\section{A nalisis D ampak M akroekonomi Restrukturisasi Perbankan di Indonesia}

Strategi restrukturisasi perbankan yang ditempuh pada dasarnya memiliki jalinan keterkaitan berbagai aspek mikro maupun makroekonomi yang cukup kompleks. Hal ini mengakibatkan tidak mudah untuk melakukan analisis dampaknya terhadap perekonomian secara menyeluruh. Oleh karena itu, analisis dalam Bab ini akan dibatasi kepada dampak dari langkah-langkah penyehatan yang telah dilakukan di sisi aktiva dan pasiva bank, termasuk permodalan, kepada upaya untuk memelihara kestabilan moneter dan pemulihan kegiatan ekonomi. Yang menjadi fokus pembahasan disini terutama adalah seberapa besar keterlibatan dana pemerintah ataupun Bank Indonesia di dalam keseluruhan proses restrukturisasi perbankan. Semakin dalam dan luas keterlibatan pemerintah dan Bank Indonesia, terutama dalam membiayai program restrukturisasi keuangan, akan semakin signifikan pula dampak dari strategi yang diterapkan kepada perkembangan dan kemantapan (sustainability) posisi fiskal, moneter maupun kondisi makroekonomi secara menyeluruh.

\subsection{Dampak makro langkah penyehatan di sisi aktiva}

Langkah penyehatan di sisi aktiva dapat dilakukan dengan membersihkan kredit bermasalah yang dimiliki bank dan meningkatkan ruang gerak pengelolaan likuiditas bank antara lain melalui penurunan giro wajib minimum (GWM). Pembersihan kredit bermasalah pada saat ini telah menjadi bagian yang integral dalam program rekapitalisasi perbankan. Aspek yang patut diperhatikan dalam kaitan dengan pembersihan kredit bermasalah ini adalah dampak dari rencana penerbitan obligasi pemerintah untuk 
menambah permodalan bank yang dinilai layak. Terlepas dari masalah jangka waktu, jenis (negotiable atau tidak), dan suku bunga instrumen ini, yang jel as akan ada tambahan beban kepada fiskal dan akan berpengaruh pula kepada upaya menjaga disiplin keuangan melalui kebijakan fiskal dan moneter yang berhati-hati.

Penyehatan sisi aktivajuga dapat dilakukan melalui peningkatan efisiensi pengelolaan likuiditas bank. Hal ini misalnya dapat ditempuh dengan menaikkan ketersediaan dana yang dapat dipinjamkan (loanablefunds) bank-bank melalui penurunan giro wajib minimum (GWM) oleh Bank Indonesia. Meskipun alternatif ini belum dilakukan, penurunan GWM akan dapat menolong mengurangi biaya dana perbankan serta dapat menurunkan suku bunga sehingga berdampak ekspansif bagi kegiatan perekonomian secara makro. Dalam situasi seperti dewasa ini dimana kegiatan ekonomi mengalami kontraksi yang tajam (sementara laju inflasi cenderung menurun dan kurs rupiah menguat) maka penurunan suku bunga diharapkan akan dapat menghentikan proses kontraksi yang terlalu tajam.

Namun, dapat dikemukakan pula bahwa penurunan GWM akan cenderung mengurangi kehati-kehatian bank dalam pengelolaan dana sehingga ketergantungan kepada fasilitas BLBI akan meningkat bila tiba-tiba terjadi pelarian simpanan. Selain itu, permasalahan yang dihadapi pada sebagian perbankan dewasa ini bukan semata-mata karena masalah kekurangan likuiditas, tetapi juga disebabkan oleh kesulitan "melemparkan" dana ke sektor riil akibat suku bunga yang tinggi sehingga mengurangi permintaan dana dari sektor riil. Meningkatkan ketersediaan dana cadangan bank dalam situasi seperti ini karenanya dapat memiliki risiko terutama kepada kestabilan kurs dan akhirnya pengendalian laju inflasi. Analisis ini oleh karenanya menunjukkan bahwa kebijakan penurunan GWM memang akan menguntungkan perbankan dari sisi mikro. Namun, efektivitas kebijakan tersebut akan lebih tinggi bila penerapannya dilakukan dalam suatu paket kebijakan ekonomi yang juga dapat mendorong penyerapan dana di sektor riil sehingga mengurangi kemungkinan munculnya dampak negatif kepada kestabilan kurs dan laju inflasi.

\subsection{Dampak makro langkah penyehatan di sisi pasiva}

Dari sisi penyehatan pasiva, kebijakan yang telah ditempuh dalam program restrukturisasi perbankan antara lain adalah penerapan skim penjaminan oleh pemerintah baik atas sisi aktiva maupun pasiva bank. Evaluasi sementara menunjukkan bahwa kebijakan ini cukup berhasil dalam meredam pelarian simpanan dan berangsurangsur mengembalikan kepercayaan masyarakat kepada perbankan nasional. Namun, ekspansi moneter yang terjadi -berupa BLBI yang pernah mencapai mencapai lebih dari Rp189 triliun atau hampir 30\% dari jumlah uang beredar (M2)- akibat penerapan skim 
penjaminan dan dampaknya kemudian kepada laju inflasi dan kurs rupiah telah mendorong diterapkannya kebijakan moneter yang ketat.

Hingga dewasa ini upaya menarik kembali dana BLBI tersebut dilakukan melalui operasi pasar terbuka. Namun, hal ini telah membawa konsekuensi secara makro yang sangat besar, terutama akibat dari kenaikan suku bunga yang tinggi. A ktivitas di berbagai sektor ekonomi tidak saja di sektor riil dan perbankan merosot tajam tetapi juga mengakibatkan pendapatan pemerintah dari perpajakan menurun sementara masyarakat luas harus mengalami penurunan tingkat pendapatan dan kekayaan secara riil. Oleh karena itu, re-evaluasi atas kebijakan penjaminan pemerintah perlu dilakukan. Paling tidak upaya mengurangi cakupan skim penjaminan layak untuk dikaji karena dapat mengurangi moral hazard, menciptakan disiplin pasar, dan mengurangi beban anggaran sekaligus meningkatkan efektivitas pengendalian moneter.

Penyehatan sisi pasiva bank bermasalah juga dilakukan melalui pemindahan pasivanya kepada bank lain, khususnya bank-bank persero, meskipun hal ini akan memerlukan tambahan dana pemerintah untuk mencegah de-kapitalisasi bank persero tersebut. Langkah ini telah ditempuh terutama dalam rangka mengurangi kerugian yang lebih besar lagi dari BBO (damage control). $\mathrm{N}$ amun, karena pemindahan tersebut dapat mendekapitalisasi modal bank pemerintah kemudian memberikan tambahan permodalan melalui penerbitan obligasi yang diserahkan kepada bank terkait ${ }^{23}$. Ini berarti langkah ini pun akhirnya akan menimbulkan masalah seberapa besar beban yang akan ditanggung oleh anggaran/ fiskal dan konsistensinya dengan upaya memelihara disiplin anggaran dan pengendalian moneter.

Langkah penyehatan yang memiliki dampak makro paling signifikan adalah kebijakan rekapital isasi perbankan. Seperti telah disinggung dal am Bab 3 penyertaan modal pemerintah dalam bank-bank yang layak akan dilakukan melalui penerbitan obligasi pemerintah. Adapun mekanisme penyertaan modal pemerintah tersebut dapat digambarkan dalam diagram dibawah ini

Langkah pertama, Pemerintah menerbitkan obligasi untuk membiayai penyertaan modal sebesar maksimum 80\% dari tambahan kebutuhan modal di bankX. Langkah yang ditempuh disini adalah "menjual" obligasi tersebut kepada Bank Indonesia. Pemerintah akan mendapatkan "uang primer" dari Bank Indonesiauntuk kemudian ditempatkan sebagai modal disetor kebankX (langkah kedua dan ketiga). Sebagai gantinya, di sisi aktivar rekening pemerintah akan terdapat saham sebesar $80 \%$ dari total kepemilikan di bank X (langkah keempat). Selanjutnya, padalangkah kelima, dengan 'uang primer' (setoran modal Pemerintah) tersebut 


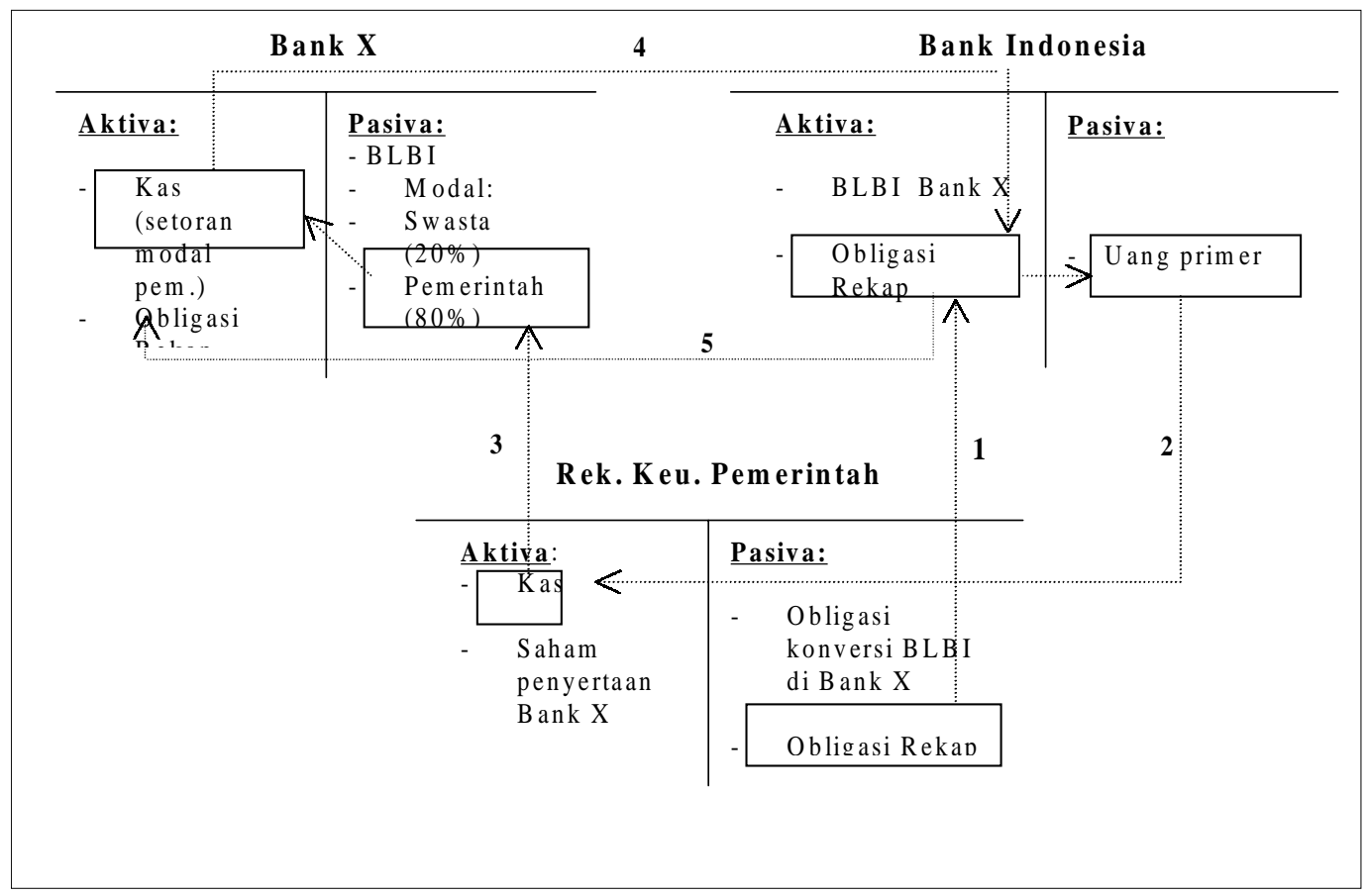

bankX dimintauntuk membeli obligasi rekap yang terdapat di tangan Bank Indonesia. Dengan demikian di sisi aktiva bank X terdapat obligasi rekap sementara 'uang primer' akan kembali ketangan Bank Indonesia. Ini berarti dalam proses penerbitan obligasi tersebut belum terjadi ekspansi (atau pun kontraksi) moneter apa pun, kecuali apabila obligasi di tangan bank $\mathrm{X}$ tersebut dapat diperjual-belikan (negotiablebonds) ${ }^{24}$.

Sepanjang instrumen yang digunakan adalah obligasi yang bersifat non-negotiable maka dampak moneter dari kebijakan tersebut bersifat netral, paling tidak pada saat instrumen diterbitkan (dalam jangka pendek). Namun, hal tersebut akan mempengaruhi pengeluaran fiskal dalam jangka menengah-panjang yang besarnya tergantung kepada jangka waktu dan suku bunga obligasi tersebut. Yang menjadi masalah disini adalah bahwa dengan APBN 1998/ 99yang diperkirakan mengalami defisit yang cukup besar, yakni sekitar 6,5\% dari PDB, maka posisi fiskal dikhawatirkan akan semakin memburuk di masa mendatang. Untuk anggaran 1999/2000 saja diperkirakan pemerintah harus menanggung bunga obligasi tersebutsekitar Rp18triliun dari total Rp34triliun. ${ }^{25}$. Menurut hemat penulis,

24 Kepastian apakah obligasi tersebut dapat diperjualbelikan hingga saat paper ini ditulis masih belum diketahui secara pasti. Namun, terdapat kecenderungan sebagian obligasi tersebut nantinya dapat diperdagangkan setelah melewati jangka waktu tertentu. Bila hal ini terjadi maka penjualan obligasi ke masyarakat dalam negeri akan bersifat kontraksi moneter, sedangkan apabila dibeli oleh masyarakat luar negeri penjualan tersebut akan bersifat ekspansif.

25 Sebesar Rp16 triliun diharapkan dapat dibayar melalui penjualan aset bank-bank bermasalah oleh AMU. Realisasi besarnya biaya bunga ini akan sangat tergantung kepada tingginya suku bunga SBI dan laju inflasi yang terjadi di kemudian hari bila obligasi yang diterbitkan menggunakan variable rate dan diindeksasi dengan inflasi. 
ini merupakan jumlah yang relatif besar sehingga tidak saja akan menjadi ancaman yang serius terhadap arus dana dan kemantapan (sustainability) posisi keuangan pemerintah dalam tahun-tahun mendatang tetapi juga terhadap pengendalian moneter akibat munculnya ekspansi moneter dari sisi fiskal ${ }^{26}$. Oleh karena itu, respons yang tepat dari sisi kebijakan fiskal dan moneter menjadi kritikal dalam menjaga kemantapan makroekonomi yang diperlukan bagi kesuksesan dari restrukturisasi perbankan itu sendiri.

\subsection{Implikasi bagi kebijakan makroekonomi dan pemulihan kegiatan ekonomi}

A nalisis sebelumnya memperlihatkan adanya beberapa dampak makroekonomi yang cukup penting untuk dicermati dalam proses restrukturisasi perbankan di Indonesia, khususnya yang terkait dengan bidang fiskal dan moneter. Oleh karenaitu, berikut disajikan implikasi dari implementasi program restrukturisasi perbankan bagi kebijakan fiskal dan moneter serta dampaknya bagi prospek pemulihan kegiatan ekonomi.

\subsubsection{Implikasi bagi kebijakan fiskal}

Seperti telah disinggung sebelumnya, beban fiskal dari program restrukturisasi perbankan ternyata akan amat besar, terlepas dari asumsi makroekonomi (suku bunga dan laju inflasi) yang digunakan. Dengan melihat situasi keuangan pemerintah yang relatif sudah sangat terbatas dan posisi utang pemerintah yang tinggi maka dengan jelas kita dapat melihat bahwa disiplin fiskal akan sulit dipertahankan (unsustainable) di masa mendatang ${ }^{27}$. Oleh karena itu, tindakan penyesuaian harus segera dilakukan baik melalui langkah konsolidasi anggaran maupun upaya mengurangi beban fiskal dalam program rekapitalisasi perbankan ${ }^{28}$.

Langkah konsolidasi anggaran dapat dilakukan dengan meningkatkan sumbersumber penerimaan dan sedapat mungkin mengurangi pengeluaran yang tidak perlu, termasuk mencegah terjadinya "kebocoran" fiskal. Selain itu, dengan cukup besarnya ancaman ketidakstabilan makroekonomi akibat defisit fiskal, maka kebijakan fiskal harus

26 Ini equivalen dengan mengatakan bahwa Bank Indonesia akan membiayai defisit fiskal melalui pencetakan uang (BLBI), meskipun dilakukan pada waktu yang tidak bersamaan (BLBI telah dikeluarkan terlebih dahulu ketika krisis perbankan mencapai puncaknya).

27 Rekening pemerintah dewasa ini hanya berjumlah sekitar Rp10 triliun, sementara beban bunga dari program rekapitalisasi untuk dua tahun anggaran fiskal mendatang saja diperkirakan akan mencapai Rp34 triliun. Dengan total utang pemerintah yang dewasa ini telah mencapai US\$45miliar maka tanpa adanya langkah penyesuaian yang drastis pada sisi pengeluaran dan penerimaan, posisi fiskal dalam tahun-tahun mendatang akan mendapatkan tekanan yang sangat berat dan bahkan mendekati kebangkrutan !

28 Menurut informasi, dewasa ini sedang ada pembicaraan antara pemerintah/Bank Indonesia dan IMF agar sebagian dana paket pinjaman IMF dialokasikan untuk menyerap beban keuangan pemerintah untuk merestrukturisasi perbankan 
dapat memainkan peran yang semakin besar dalam menanggulangi shocks di masa-masa mendatang, misal nya ketika tekanan inflasi tiba-tiba meningkat maka kebijakan fiskal harus dapat secara fleksibel mengurangi dampak ekspansi dari pengeluarannya.

U paya untuk mengurangi beban fiskal dalam program rekapitalisasi dapat dilakukan dengan merancang-bangun suatu program "cost recovery" yang lebih cepat atas aset bermasalah yang telah diserahkan ke AMU, misalnya melalui pelelangan setelah batas waktu penyelesaiannya dilewati. Setiap hasil dari penyelesaian kredit bermasalah kemudian akan digunakan untuk membayar kembali utang bank kepada pemerintah atau Bank Indonesia. Dari sudut mikro upaya ini sangat ideal bila dapat dilakukan secara transparen dan tegas karena dapat mengurangi moral hazard, menciptakan disiplin keuangan, dan disiplin pasar yang lebih baik di sektor perbankan. Dari sudutmakro, selain akan mengurangi beban fiskal juga dapat lebih meringankan beban operasi pasar terbuka Bank Indonesia dalam upaya menarik kembali ekspansi uang beredar (terutama yang berasal dari BLBI) sehingga beban penggunaan instrumen suku bunga akan dapat berkurang. Selain itu, ketegasan dalam langkah ini akan dapatmemperbaiki kepercayaan masyarakat, baik dalam dan luar negeri, sehingga ikut menciptakan iklim yang lebih kondusif bagi pemulihan kegiatan di sektor perbankan dan perekonomian secara keseluruhan.

\subsubsection{Implikasi bagi kebijakan moneter}

Seperti disinggung sebelumnya, dampak moneter dari program rekapitalisasi perbankan dalam jangka pendek bersifat netral apabila obligasi tersebut tidak diperdagangkan. Penerbitan obligasi pemerintah dan konversi BLBI menjadi saham hanya menyebabkan tagihan Bank Indonesia kepada perbankan menjadi beralih kepada pemerintah sehingga tidak terdapat ekspansi moneter yang riil pada saat dilakukan. Meskipun demikian, seperti diulas di atas, dampak ekspansi moneter dari penerbitan obligasi tersebut baru akan dirasakan dalam beberapa tahun mendatang ketika biaya bunga program restrukturisasi perbankan mulai harus dibayarkan oleh pemerintah.

Hal ini dengan sendirinya akan membawa implikasi kepada pengendalian moneter. Seperti diketahui, dewasa ini uang beredar masih tumbuh tinggi. A nalisis sederhana berdasarkan rumus MV =PT terlihat bahwa ekspansi uang beredar (M2) dewasa ini berada di balik tingginya inflasi (P) meskipun sebenarnya kegiatan ekonomi $(\mathrm{T})$ telah mengalami kontraksi yang sangat dalam. ${ }^{29}$ Fakta yang ada menunjukkan bahwa hampir 30\% dari uang beredar (M2) berasal dari BLBI. Dengan situasi seperti ini, bila dampak ekspansif dari sektor fiskal seperti diuraikan pada sub 4.2.1. diperhitungkan, maka cukup sulit bagi kebijakan

29 Diasumsikan velositas uang beredar atau V juga cenderung meningkat dalam suasana inflasi yang tinggi. 
moneter untuk dapat dengan cepat melonggarkan likuiditas di dalam perekonomian mengingat ancaman hyperinflation belum seluruhnya dapat dikendalikan. ${ }^{30}$ Ini berarti suku bunga akan harus relatif tetap tinggi, kecuali bila laju inflasi akan dapat menurun dengan cepat dalam beberapa waktu kedepan.

Namun demikian, tetap tingginya suku bunga akan menimbulkan permasalahan yang menurut hemat penulis jauh lebih serius, terutama dalam jangka pendek ini. Sebagai akibat dari tingginya suku bunga dewasa ini, kerusakan yang dialami oleh sektor riil telah amat dalam dan meluas sementara tingkat pengangguran dan kemiskinan mencapai tingkat yang amattinggi sehingga menimbulkan biaya sosial yang amat tinggi pula. Sektor perbankan juga telah merasakan dampak negatif dari suku bunga yang tinggi tersebut dengan munculnya "negative spread" sebagai respons dari upaya mengurangi peningkatan kredit bermasalah di sisi aktiva. Di samping itu, tingginya suku bunga juga mengurangi minat bank untuk menyalurkan dananya kesektor riil dan lebih memilih SBI sebagai instrumen investasinya. Bahkan telah banyak bank melakukan percepatan pelunasan kredit yang masih tergolong lancar dengan menawarkan diskon, semata-mata untuk mendapatkan uang tunai untuk kemudian ditanamkan ke SBI. Oleh karena itu, berbagai perkembangan ini menunjukkan bahwa upaya menjaga kemantapan makroekonomi melalui suku bunga tinggi tidak dapat berlangsung terlalu lama. Kerusakan yang diakibatkan oleh kebijakan tersebut justru akan dapat merusak kembali kondisi makroekonomi itu sendiri. Padaakhirnya, hal tersebutakan mengganggu keberhasilan restrukturisasi perbankan dan upaya pemulihan kegiatan ekonomi.

Menghadapi permasalahan yang dilematis ini, menurut hemat penulis, perlu dilakukan kompromi dengan menjadwal ulang jangka waktu pencapaian sasaran-sasaran moneter. Fleksibilitas kebijakan pengetatan moneter harus dirancang-bangun sedemikian rupa agar dalam jangka pendek sasaran menggerakkan kembali roda perekonomian dapat dilakukan. Hal ini amat penting untuk mengurangi risiko kredit yang dihadapi perbankan sehingga diharapkan juga ikut membantu kelancaran restrukturisasi perbankan. Sementara itu, sasaran kebijakan moneter dalam jangka panjang dapat diarahkan kepada upaya menurunkan laju inflasi mengingat adanya ancaman potensial dari defisit yang besar di sektor fiskal.

\subsubsection{Implikasi bagi pemulihan kegiatan ekonomi}

Dari analisis di atas didapat gambaran bahwa pelaksanaan program restrukturisasi perbankan, khususnya dal am program rekapitalisasi, akan melibatkan adanya tambahan

30 Dewasa ini tekanan penyesuaian harga DN ke arah harga LN masih cukup besar (the law of one price). Dengan melihat nilai tukar rupiah secara riil (REER =kurs + inflasi Indonesia - inflasi USA) yang dewasa ini undervalued sekitar $70 \%$ berarti akan ada kecenderungan kembalinya REER menuju 'purchasing power parity'. Hal ini dapat melalui apresiasi $\mathrm{Rp}$ atau tingkat harga yang akan lebih dulu melakukan penyesuaian ke atas. 
dana guna memperkuat permodalan perbankan dalam jumlah yang sangat besar. A pabila seluruh tambahan dana tersebut berupa dana segar sehingga secara efektif menambah likuiditas perbankan, maka tentu dampak yg ditimbulkan kepada kegiatan perekonomian akan sangat positif. Namun, seperti diketahui, sebagian besar dana rekapitalisasi sebesar Rp330 triliun akan diberikan dalam bentuk obligasi pemerintah yang tidak serta merta mempunyai dampak moneter, meskipun akan mempengaruhi posisi utang pemerintah. Sementara sisanya diharapkan berasal dari dana segar dari pemilik atau investor baru. Ini berarti dampak langsung program restrukturisasi perbankan kepada sisi permintaan (kegiatan investasi dan konsumsi) dan sisi penawaran (produksi) secara keseluruhan tidak akan terlalu signifikan dalam jangka pendek, mengingat kemungkinan kecilnya dana segar yang akan masuk.

Dampak positif yang besar kepada kegiatan perekonomian akan lebih dirasakan secara tidak langsung, bila program restrukturisasi berhasil menyehatkan posisi keuangan bank, baik dari sisi aktiva (terutama pembersihan kredit bermasalah) maupun sisi pasiva (meningkatkan permodalan). Dengan restrukturisasi perbankan yang berhasil maka secara berangsur-angsur fungsi intermediasi perbankan akan dapat diberdayakan kembali. Perbaikan efisiensi dan posisi keuangan yang lebih sehat juga akan memungkinkan biaya dana yang lebih rendah sehingga memacu penurunan suku bunga. A pabila perkembangan ini diikuti pula oleh keberhasilan penyehatan di sektor riil, secara gradual permintaan terhadap kredit akan meningkat sehingga akhirnya roda perekonomian berputar kembali.

Namun demikian, dari analisis pada Bab 3 sebelumnya, didapat gambaran bahwa proses restrukturisasi perbankan tampaknya akan mengalami banyak hambatan, paling tidak dalam jangka pendek ini. Hal-hal yang diperkirakan akan menghambat kelancaran pelaksanaannya terutama adalah lemahnya koordinasi di antara pihak pembuatkebijakan, dan kurangnya dukungan dari segi legal dan politis, terutama bagi operasionalisasi unit penyehatan bank (BPPN dan AMU). Selain itu, dengan situasi makro yang cenderung memburuk akibat kontraksi kegiatan ekonomi yang tajam ${ }^{31}$, maka program restrukturisasi perbankan akan pula menghadapi hambatan dari sisi eksternal, yakni lingkungan yang kurang kondusif.

Berbagai kecenderungan ini menunjukkan bahwa proses pemulihan ekonomi Indonesia tampaknya akan sulit diharapkan dapat berlangsung cepat. Perkiraan ini sebenarnya telah dapat dilihat dari relatif lambannya stabilisasi perkembangan beberapa indikator ekonomi-moneter di Indonesia bila dibandingkan dengan negara-negara di kawasan Asean yang juga mengalami juga krisis ekonomi. Meluasnya kerusakan pada kapasitas produksi dan tajamnya penurunan permintaan aggregat akibat dari penerapan

31 Angka sementara pertumbuhan PDB tahun 1998 menunjukkan kontraksi sekitar minus 13-14\%. 
kebijakan moneter yang terlalu ketat dikhawatirkan akan semakin mempersulit perbankan nasional. Oleh karena itu, tanpaadanya kemajuan yang berarti dalam program restrukturisasi perbankan serta perubahan orientasi kebijakan makroekonomi, khususnya moneter, maka pemul ihan kegiatan ekonomi akan sul it dilakukan dalam waktu dekat ini.

\section{Penutup}

Upaya mengatasi krisisperbankan dewasa ini merupakan masalah yang dilematis. Pemerintah dihadapkan pada dua pilihan yang sama sulitnya. Menyediakan dana yang begitu fantastis jumlahnya atau negara kita akan kehilangan perbankan nasional. Pilihan untuk tetap mempertahankan eksistensi perbankan nasional, wal aupun harus dibayar sangat mahal, merupakan strategi yang tepat.

Dengan berbagai kebijakan yang telah diambil hingga saat ini, proses restrukturisasi telah mulai memasuki tahap yang menentukan dalam proses penyehatan posisi (masalah stock) keuangan perbankan. Hal ini tercermin dari berlangsungnya program rekapitalisasi perbankan yang selanjutnya akan diikuti oleh proses "penyiangan" atas bank-bank yang dinilai tidak layak operasi. Tahapan selanjutnya adalah penyehatan sistem dan lingkungan eksternal agar perbankan dapat beroperasi secara menguntungkan dan berkesinambungan (restrukturisasi operasional). Namun demikian, hingga dewasa ini penulis berpendapat persiapan menuju tahap ini belum sepenuhnya direncanakan secara komprehensif. Visi dan strategi pengembangan industri perbankan masa depan masih belum secara tegas ditetapkan sehingga mengakibatkan konfigurasi industri perbankan belum dapat tergambar dengan jelas.

Relatif lambatnya proses restrukturisasi perbankan di Indonesia bila dibandingkan dengan negara-negara tetangga yang juga melakukan program yang sama, menurut pengamatan penulis, lebih disebabkan oleh belum adanya 'lead agency' yang efektif dalam membuat suatu "grand strategy" dan berwewenang penuh atas keberhasilan program restrukturisasi perbankan. Lembaga-lembaga yang menangani restrukturisasi perbankan relatif banyak, mulai dari Bank Indonesia, Departemen Keuangan, BPPN , Bappenas, hingga Menko Ekuin, sehingga koordinasi yang efektif sulit tercapai. Sementara itu, dukungan politis, terutama dari DPR, dan hukum juga kurang memadai. Selain itu, belum adanya visi yang jelas tentang arah restrukturisasi membuat seringnya kebijakan mengalami perubahan secara mendadak sehingga berakibat memperlambat kelancaran program itu sendiri.

Analisis terhadap dampak makroekonomi dari restrukturisasi perbankan juga menunjukkan bahwa program rekapitalisasi merupakan salah satu titik kritikal yang menentukan keberhasilan restrukturisasi perbankan dan upaya pemulihan ekonomi. Penggunaan instrumen obligasi pemerintah dalam program rekapitalisasi perbankan 
diperkirakan akan potensial memberikan tekanan yang berat baik kepada pengendalian moneter maupun keuangan negara dalam jangka menengah-panjang. Oleh karena itu, langkah preventif yang terencana dengan baik untuk mengatasi atau setidaknya mengurangi dampak negatif dari program rekapital isasi harus dilakukan sesegeramungkin secara serius.

Agar program restrukturisasi perbankan dapat berhasil dengan lebih baik, terdapat beberapa hal yang kiranya dapat di lakukan dalam waktu dekat ini. Pertama, pembentukan suatu lead agency yang berwenang penuh terhadap proses restrukturisasi perbankan dan bertanggungjawab penuh atas keberhasilannya. Menurut penulis, BPPN merupakan kandidat yang dapat dipertimbangkan menjadi badan pengendali restrukturisasi perbankan karena pengalamannya. Untuk itu, sesuai dengan kewenangan Bank Indonesia menurut Undang-Undang Perbankan yang baru, Bank Indonesia dapat menugaskan BPPN melakukan restrukturisasi perbankan dengan kewenangan yang penuh. Usulan ini dimotivasi oleh pengalaman di banyak negarayang telah menunjukkan bahwa keterlibatan bank sentral dalam restrukturisasi perbankan cenderung memperlambat proses restrukturisasi itu sendiri. Hal ini terutama disebabkan oleh munculnya benturan kepentingan antara tugas penyehatan bank dan pemeliharaan kestabilan moneter ${ }^{32}$. Selanjutnya, dalam jangka panjang patut dikaji pula kemungkinan memindahkan fungsi supervisi perbankan dari Bank Indonesia keBPPN, tentunya dengan mengubah namaagar tidak terkesan hanya berfungsi sekedar menyehatkan bank. Langkah ini selain akan meningkatkan kredibilitas Bank Indonesia sebagai otoritas moneter juga akan dapat mendorong profesional isme supervisi perbankan. Kedua, pengurangan sedapat mungkin beban fiskal dari berbagai langkah penyehatan bank melalui "cost recovery" yang efektif. Langkah-langkah yang searah dengan tujuan ini antara lain:

- Percepatan program pengembalian BLBI baik dalam rangka persyaratan mengikuti program rekapitalisasi maupun pelelangan aset oleh AMU.

- Pengurangan secara bertahap skim blanket guarantee, dengan lebih melindungi simpanan masyarakat sejalan dengan kemajuan yang dicapai dalam program restrukturisasi perbankan. Namun demikian, langkah ini harus tetap dilakukan dengan berhati-hati mengingat masih labilnya kepercayaan masyarakat terhadap perbankan dewasa ini.

Ketiga, peninjauan ulang jadwal pencapaian sasaran-sasaran moneter dalam jangka pendek dan reorientasi penekanan pencapaian sasaran dalam jangka menengah-panjang. Secara ringkas usulan ini akan berarti merevisi keatas (lebih longgar) sasaran pengendalian moneter guna memberikan ruang gerak yang lebih besar kepada perbankan menurunkan suku bunga apabila proses restrukturisasi keuangan perbankan telah dilakukan. Selanjutnya,

32 Lihat WE Alexander, et.al (1997) halaman 141. 
pengendalian moneter dapat lebih diarahkan untuk mengendalikan laju inflasi dalamjangka menengah-panjang, sejal an dengan perkembangan (ekspansi) sisi fiskal akibat pembayaran bunga obligasi pemerintah dan pengeluaran lainnyayang dapat menyebabkan pertumbuhan likuiditas berlebih di dalam perekonomian. Ini berarti, koordinasi dengan kebijakan fiskal serta fleksibilitas pengendalian fiskal harus lebih berperan dalam mengurangi tekanantekanan ekspansif pada uang beredar.

Sebagai catatan penutup, kegagalan di waktu yang lalu dalam memelihara sistem perbankan yang sehat, sebenarnya bukan karena tidak dimilikinya pengetahuan bagaimana seharusnya sistem perbankan yang baik ditata. Kegagalan justru muncul karena adanya keraguan dan keengganan untuk secara konsisten menata sistem perbankan yang baik, sambil berharap semoga tidak terjadi sesuatu yang luar biasa yang dapat memperburuk sistem perbankan. N amun demikian, ternyata sesuatu yang luar biasa tersebut benar-benar terjadi. Oleh sebab itu, belajar dari pengalaman masa lalu tersebut, tampaknya kita harus mulai lagi memantapkan hati, apapun risikonya bagi pembuat keputusan, termasuk jajaran aparatnya, untuk benar-benar menata sistem perbankan sesuai dengan tatanan perbankan yang sehat.

\section{D aftar Pustaka}

Alexander, William E., Jeffrey M. Davis, Liam P. Ebrill, and Carl-Johan Lindgren, Systemic Bank Restructuring and M acroeconomic Policy, IMF, Washington D.C.,1997

Benston, GeorgeJ et. al, Perspectives on Safeand Sound Banking - Past, Present, and Future, Cambridge, Massahusetts, MIT Press, 1986

Daniel, James A., Fiscal A spects of Bank Restructuring, IMF Working Paper 97/ 52, Washington D.C.,1997

Flood, R. and Peter Garber, A Systematic Banking Collapse in a Perfect Foresight W orld, NBER Working Paper N o.691, 1981

Ibrahim, Maulana, Strategi Restrukturisasi Perbankan, Bahan Diskusi pada SESPIBI XXIII, Jakarta, 1998

Khan, Mohsin, and M.Knight, "Stabilisation Programs in Developing Countries: A Formal Framework", I M F Staff Papers, 1981

Kindleberger, C.P., M ania, Panics, and C rashes: A H istory of Financial Crises, New York, Basic Books, 1978

Laporan Tahunan Bank Indonesia 1997/ 98, Jakarta, Mei 1998 
Lindgren, Carl Johan, Gilian Garcia, and Matthew Saal, Bank Soundness and M acroeconomic Policy, IMF, Washington D.C., 1996

Pazarbasioglu, Ceyla and Jan Willem van der Vossen, "Main Issues and Challenges in Designing Bank-Restructuring Strategies", in Central Bank R eform in theTransition Economies, ed by Sundararajan, A rnePeterson, and Gabriel Sensenbrenner, IMF, Washington D.C.,1997.

Prawiranata, Iwan R., Gambaran Pelaksanaan Penyehatan Bank, Bahan Diskusi pada SESPIBI XXIII, Jakarta, 1Oktober 1998

Sheng, Andrew, Bank Restructuring : Techniques and Experience, Washington D.C., 1992

Sundararajan V and Thomas J.T. Balino, Banking Crises: Cases and Issues, IMF, Washington D.C., 1991 